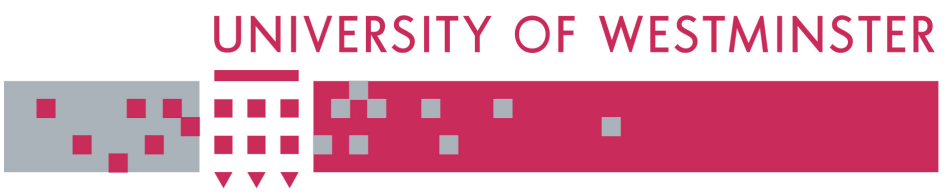

WestminsterResearch

http://www.wmin.ac.uk/westminsterresearch

\title{
The European construction social partners: gender equality in theory and practice.
}

\section{Linda Clarke}

Elsebet Frydendal Pedersen

Elisabeth Michielsens

Barbara Susman

Westminster Business School, University of Westminster and Danmarks Tekniske Universitet, DENMARK

This is an electronic version of an article published in the European Journal of Industrial Relations, 11 (2). pp. 151-177, July 2005. (C) Sage Publications. The definitive version is available online at:

http://ejd.sagepub.com/cgi/reprint/11/2/151

The WestminsterResearch online digital archive at the University of Westminster aims to make the research output of the University available to a wider audience. Copyright and Moral Rights remain with the authors and/or copyright owners. Users are permitted to download and/or print one copy for non-commercial private study or research. Further distribution and any use of material from within this archive for profit-making enterprises or for commercial gain is strictly forbidden.

Whilst further distribution of specific materials from within this archive is forbidden, you may freely distribute the URL of WestminsterResearch.

(http://www.wmin.ac.uk/westminsterresearch).

In case of abuse or copyright appearing without permission e-mail wattsn@wmin.ac.uk. 
Linda Clarke, Elsebet Frydendal Pedersen, Elisabeth Michielsens and Barbara

Susman

University of Westminster, UK and Danmarks Tekniske Universitet, DENMARK

\title{
The European Construction Social Partners: Gender Equality in Theory and Practice
}

\begin{abstract}
This article explores the social partners' role in the gender equality agenda in construction at skilled operative level. It draws on a survey of the European construction social partners that investigated the presence of women in skilled trades and the policies, collective agreements and practices that play a role in women's integration. The responses indicate that the construction industry still displays inertia and conservatism, and that the social partners corroborate rather than counter this. They express a 'discourse' of gender equality, but this does not automatically lead to equal opportunity policies or programmes. The social partners have the platform to make inroads and to change the industry from within, but need further encouragement to put this on their agenda.
\end{abstract}

\section{Introduction}

There are few sectors in Europe where gender segregation in the labour market is more evident than the construction industry, particularly at skilled operative level. In this article, we explore the position of the social partners towards the gender equality agenda, especially regarding skilled trades such as carpenters, painters and bricklayers. We ask whether the social partners in construction 
advance the inclusion of women, in line with the European employment and equality agenda, or whether they are guilty of preserving women's present marginalization.

The article draws on a survey of the social partners in construction in both west and east Europe. This investigated the presence of women in skilled trades in each country and the existence of policies, collective agreements or practices that play a role in their integration. The findings show that there are few exceptions to the dominant picture of low female representation in construction, little changed over the past ten years. The social partners have had little impact on increasing the representation of women in the industry overall and there appear to be few internal or external forces driving them to change the situation.

EU social and employment policies have a long-standing focus on gender inequalities in Europe, embracing the principles of equal opportunities and gender mainstreaming. Key objectives are to reduce both the gender pay gap and sectoral as well as occupational gender segregation, which are seen as creating 'rigidity in the labour market, reducing the market's ability to respond to change' (EC, 2001). However research shows that the impact of this agenda in national member states remains uneven, and that there is a tension between the targets of increasing participation and reducing segregation (Gonäs, 2004; Rubery et al., 2003).

The social partners (ETUC, UNICE and CEEP) play a very important role in regulating European employment and equality issues (Léonard, 2001). The first two agreements reached under the Maastricht procedures and subsequently adopted as directives --- on parental leave (1995) and part-time work (1997) --- had clear gender equality implications. EU policy puts considerable stress on the potential of collective agreements to address labour market inequalities: 'if collective bargaining lacks a gender perspective, it is very likely that agreements will institutionalise discriminatory practice, entrench rather than challenge gender segregation of work, and operate on a male norm of employment, to the obvious disadvantage of women' (eiro, 2000). Yet are the social partners really in the forefront in ensuring the implementation of this agenda at European and national levels?

Much research has addressed the role of trade unions on gender issues (for instance, Cockburn, 1991; Dickens, 2000; Kirton and Greene, 2002; Wajcman, 2000). Colgan and Ledwith (2002) 
provide an international overview of unions and the promotion and participation of women, revealing a wide range of different agendas across the globe. Research on women's groups or committees in unions confirms their role as catalysts for change, contributing to an environment where "women can develop strengths and advance their concerns' (Foley, 2003; Parker, 2003). Studies by Munro (2001) and McBride (2001) in the UK indicate that women's equality and employment issues have become part of the central agenda of unions such as Unison, which operate in areas of high female employment. The actions of trade unions to promote the participation of women and the incorporation of gender equality issues can however be summarized as more reactive than proactive.

In this article, we explore the actions of the social partners in a sector in which women's employment and therefore female representation is minimal. The European social partners may have taken part in setting the European equality agenda of increased female participation in the workplace and reduction of gender segregation, but how far has this agenda been embraced and implemented by the national social partners in construction? As this is a very important and at the same time highly male-dominated sector, it is particularly critical to the European aim of reducing gender segregation. The east European social partners have not been fully part of this European employment agenda, but the comparison with their west European partners is illuminating as the pattern of employment of women is very different (Pollert, 1999).

Women's participation in construction in Eastern Europe remains high despite the weakness of the social partners, and this indicates the problem we face in establishing how far the social partners themselves exert an impact on the gender division of labour (Clarke et al., 2003). Recent research has shown that the structures and mechanisms of gender exclusion differ across Europe, depending on the productive system in place (EC Consortium, 2003). In the highly regulated, skilled and industrialized construction industries of northern Europe, in particular Germany, the Netherlands and Scandinavia, entry depends very much on formal qualifications and hence on the training system (Bosch and Philips, 2002, Clarke and Wall, 2000). In the more craft-based and unregulated industries of southern Europe and even Britain, in contrast, where skills are often acquired on the job, employment is much more casual and the training system has far less importance as a 'gatekeeper' to entry. In terms of employment and the wage system, too --- factors upon which social partners can 
have a decisive impact --- the prevalence of labour-only subcontracting, casual employment and piecework appear to have far more exclusionary gender implications than firm-based systems of stable employment and time-based, graded wage systems (Byrne et al., 2004). Thus each country will have a different combination of factors which influence gender exclusion. In the Netherlands, for instance, this has been attributed to recruitment from the countryside, lack of political will on the part of the social partners and the training institutions (EC Consortium, 2003; Westerhuis, 2004).

National institutions do not excuse the social partners from their role in perpetuating and even reinforcing gender exclusion in construction. There is ample evidence that they have played a critical role in enforcing the gender division of labour, for example in post-war Britain when the trade unions colluded with the employers and the state in excluding women from skilled work (Boston, 1987; Clarke and Wall, 2004). In Germany at the same time, women were also increasingly and systematically excluded from construction in the western zones, in contrast to the east (Janssen, 2004).

Our intention here is not only to chart the situation but to identify where the construction social partners have taken initiatives to be more gender-inclusive and why in certain places actions appear to be successful.

\section{European Level: Gender Equality and Social Partners in Construction}

The construction sector plays a significant part in the European economy: in 2002 it accounted directly for 8 percent of employment (more than 12.7 million persons) and indirectly for up to 20 percent (EC, 2002a). In many EU countries, including Britain and Italy, severe skill and labour shortages are reported, with the additional immigrant --- as opposed to female --- workforce insufficient to cover increased demand.

How many women work in construction? The majority of women working in the west European construction sectors undertake administrative, technical and professional work. European 
Labour Force Survey statistics do not allow us to distinguish between occupations: the figures combine manual and administrative and professional occupations. Nevertheless, even in aggregate terms women are severely under-represented in each west European country (there is no comparable east European information). Three blocks can be distinguished: Germany and Switzerland have the highest female employment in their national construction sectors (13 and 12 percent respectively); the Mediterranean block of Spain, Portugal and Greece (5, 4 and 2 percent) has the lowest representation of women; whilst Scandinavia (Sweden 7 percent, Norway and Denmark 8 percent, Finland 9 percent) together with the Netherlands and Belgium ( 8 and 7 percent) take a middle position, around the EU average of 9 percent (EC, 2002a). Data on women in manual trades are scarce to non-existent, but the available information suggests that in most countries these represent less than 1 percent of the workforce at skilled operative level (Byrne et al., 2005).

After commerce, construction is the largest sector where a sectoral social dialogue exists at European level and is covered by EU protocols (EC, 2002b). Most of the national employers' federations are affiliated to the European Construction Industry Federation (Fédération de l'industrie européenne de la construction, FIEC), which, with a membership of 32 federations in 25 countries, is more representative than its main alternative, the European Builders' Confederation. The trade unions are part of the European Federation of Building and Wood Workers (EFBWW) and the Nordic Federation of Building and Wood Workers (NBTF), the European arms of the International Federation of Building and Wood Workers (IFBWW), which (as their titles indicate) cover both the construction and woodworking industries. With some exceptions, in particular Greece, EFBWW and NBTF represent all the building trade unions in EU member states that have collective bargaining power.

Collective bargaining has survived in the construction industry in most European countries (Schnepf et al., 1997). At European level, construction has one of 26 sectoral social dialogue committees bringing together European-level representatives of trade unions and employers for discussions on employment, competitiveness and social issues (EC, 2002b). Since 1999 this has taken place in a more formal way through the committee for the construction sector on which FIEC and EFBWW are representatives. The main themes discussed are health and safety, the image of the 
sector, life-long learning, social dumping, posted workers and the consequences of EU enlargement (EC, 2003).

In 2000 a joint declaration on employment was signed, but there is no evidence of consideration of workforce diversity, gender issues or equal opportunities. In contrast, other sectoral committees have addressed these issues: for instance, codes of conduct on fundamental rights and equal opportunities have been signed in leather and tanning, footwear and hairdressing, while good practice guides have been adopted in textiles, clothing and postal services, and the telecommunications industry has established a diversity working party covering subjects such as equal opportunities and disabled and migrant workers.

Neither FIEC nor EFBWW has women's or equal opportunities committees or working groups. The FIEC subcommittee on vocational training does however consider that the issues relating to encouraging young people into the industry are very similar to those that would attract women. At a subcommittee meeting in 2001, discussions of common concern emerged on the following issues: recruiting and retaining young people in the sector, training trainers, the equivalence of diplomas, worker mobility, the use of new technology in the field of vocational training and the recruitment of women (FIEC, 2002). On the union side, only the IFBWW has a stated commitment to women's rights: one of the nine priorities of its strategic plan for 2001-05 is to 'promote and support women', and in October 2002 its conference on Europe for the first time elected a European Women's Committee (IFBWW, 2003).

The issues of the integration of women and gender equality do not therefore appear to have a place on the agenda of the social dialogue at European level, although they might be addressed on the margins when discussing other matters. If not at European level, perhaps there is a debate at national social partner level? As no comparative information on this was available, a survey of the European social partners in construction (including in Eastern Europe) was undertaken by the authors.

\section{National Level: Gender Equality and Social Partners in Construction}


There is at national level across Europe a diversity of unions representing the interests of building workers. In Germany building workers are represented by a single union, IG BAU; in other countries the trade unions are split along occupational lines, as in the UK and Denmark or along political and/or religious lines, as in Switzerland, France and Italy (Schnepf et al., 1997). Trade union density varies from 85-90 percent in Denmark, Finland, Sweden and Belgium, to 60 percent in Italy and 40 percent in Germany, 21 percent in the UK (14 percent in the private sector) and 10 percent in Spain (Byrne and van de Meer, 2002). Membership levels in some countries do not necessarily reflect the representativeness of the unions or coverage of collective agreements, particularly when the principle of erga omnes applies (as in France and Germany), extending coverage of collective agreements to all employees.

Associations at national level represent the construction employers' interests in diverse ways. In many countries they are divided by firm size or area of construction activity; for instance, in France and Germany separate associations represent smaller craft firms. In some countries, such as the UK, one national confederation (the Construction Confederation) represents the interests of the different federations at national and European level. A relatively high level of employer representativeness is found across Western Europe, though not everywhere (for instance, coverage is lower in Spain and to a lesser extent the Netherlands). The level of employer organization is in many countries similar to that of unionization, giving a strong basis for negotiation. However, it is notable that in Spain employers have an even lower level of organization (5 percent) than the unions, whilst the reverse is true in the UK with a rate of over 80 percent (UCL, 2001). In the east European countries, employee organization is especially weak or even non-existent, more so than membership of the company-based unions (Clarke et al., 2003).

In order to investigate the extent to which women are represented in skilled trades and equality issues figure on the social partners' agenda, we conducted a survey in 2003. A questionnaire was sent to employer and trade union organizations, covering such topics as the numbers and occupations of women workers in the member firms or union (particularly in the skilled trades); women's involvement in the union or employers' organization; the inclusion of work-life balance issues in 
collective agreements (such as maternity pay or hours); the obstacles to women's access to the sector; and recommendations to overcome these.

Trade unions and employers organizations were contacted by different routes. For trade unions, a postal questionnaire was sent to $50 \mathrm{EFBWW}$ members and 25 east European affiliates, in one of six languages as appropriate. In total, after follow-up contact, 21 trade unions completed the questionnaire. All nine of the Scandinavian trade unions contacted completed the questionnaire; the other responses came from Spain and the UK (two each) and one each from France, Germany, Italy, the Netherlands and Switzerland in the west, and Bulgaria, the Czech Republic, Russia and Serbia in the east.

The survey of employers' organizations took place in collaboration with FIEC, which distributed the questionnaire to the 21 members of its Vocational Training Working Group (SOC-1). Twelve responses were received: from Cyprus, Denmark, Finland, France, Germany, Italy, Portugal, Norway, Sweden and the UK, and from the Czech Republic and Slovakia.

Significant omissions included UCATT (the Union of Construction and Allied Technical Trades), the union with the largest share of construction workers in the UK; and the French construction unions. On the positive side, replies from all the Scandinavian social partners were especially valuable, enabling us to examine, for example, whether the increase in the number of women painters in Denmark was part of a larger regional trend or not. The low response rate, particularly from the trade unions, and the lack of response from important unions in the larger EU countries despite repeated follow-ups, whilst influencing our data also reflects a lack of concern with the subject.

\section{Skilled Women Workers in Construction}

The data from both the employer and trade union organizations confirm very low numbers of women working in the sector (and therefore as members), generally reported to be less than 10 percent. This 
is consistent with overall figures of 8.6 percent for female employment in the sector in Europe (EC, 2002a). On the employers' side, only the French Building Federation presented data on operatives, with the number of women craftworkers put at 1.1 percent. More trade-specific information was given by the unions. Table 1 gives an overview for each of the unions, including: the occupations it covers (which varies greatly); the proportion of women members (of the construction part of the union only); their occupations; the percentage of the construction labour force unionized; and the total union membership in construction. In countries where union membership is high, we can assume that most if not all women are included in the information provided, especially for the manual trades.

[Table 1 about here]

The manual occupations covered by the construction unions differ. In Finland and Germany, cleaners are included in the construction union and in Sweden they represent the majority of women members. Although women are to be found in the unions in increasing numbers, the vast majority work not as tradeswomen but in administrative and increasingly in technical and professional occupations, with architecture and engineering specifically mentioned. Increases in female membership were reported by the Danish painting union, Malerforbundet $i$ Danmark (+800), the Dutch building union FNV-Bouw (+10 percent, mostly in support jobs), the Spanish construction union ELA and the Italian general construction and wood industry union, FILCA-CISL. The German union IG BAU, which experienced a fall in overall membership levels because of the crisis in the sector, is campaigning to recruit more women cleaners and for improvement in their working and employment conditions. Wages and conditions in cleaning are generally considered poor, and currently only 6.4 percent of the nearly 400,000 employees in the area are union members (EIRO, 2001). However, women constitute as much as 15 percent of the membership of IG BAU, half of these in cleaning, 14 percent in gardening and agriculture and 11 percent in professional and technical occupations, including architectural and engineering offices (IG BAU, 2004). 
The Nordic countries present some interesting exceptions to the general picture of very few women (around 1 percent) in manual trades in the old EU countries. A significant proportion of painters are women in Denmark (33 percent) and Finland (10 percent). In Denmark, the number of female painting apprentices is now equal to male (Pedersen, 2004). This 'breakthrough' is attributable to a number of specific factors. Health and safety concerns in the 1970s led to a labour shortage in the trade, after which employers looked to women as potential recruits (Clarke et al. 1999). The move to a vocational college-based training system, lessening the dependence on employers, has also played a role in consolidating women's presence in the trade. But even where women have made significant gains, there remain barriers. The Danish Painters Employers' Federation, though noting that some women own small firms and that sole traders might not be members, reports that only $2-3$ percent of its 1,500 member firms are owned by women. The Danish electricians' union, Dansk El-Forbund, also reports increasing numbers of women electricians, 5 percent of members, and cites the reason for this as the decrease in the physical demands of the work.

In the UK, against a background of almost total exclusion, small pockets of women are to be found working for public sector employers in local authority building departments or DLOs (direct labour organisations) (Clarke and Wall, 2004). But overall women's participation has decreased: in a survey of building occupations in the private sector the proportion of women building trade operatives in the UK was found to be 0.2 percent, with the highest proportion in painting, at 0.8 percent (CITB, 2002). In the UK this decline is generally attributed to the declining importance of the DLOs since the 1980s (Michielsens et al., 1997). A similar situation can be seen in the Netherlands, where female membership has also fallen.

The Italian figure for female union membership in construction is revealing of the gender difference between factory- and site-based work, with tradeswomen more likely to be found working in workshops than on site; in FILCA-CISL women represent 1 percent of membership in construction (site), but 30 percent in the wood industry (workshop). In Spain, where the construction industry, in common with the UK, has high levels of self-employment, temporary work and casual labour, including immigrants (all factors militating against women), women's presence on site has been claimed to be 'purely anecdotal' (Byrne and van de Meer, 2002). 
Eastern Europe provides a contrast: women do not play an equal role in the industry but there is significantly greater integration into the workforce. Though female union membership is not broken down by trades, this is overall much higher than in west European countries, at 20 percent in Serbia, 25 percent in the Czech Republic and 35 percent in Russia. Women members are found not only in professional occupations --- as architects, designers and managers --- but also as machine operators, crane drivers, painters and plasterers. Women's employment in the construction industry and female union membership have decreased in most east European countries since the end of the Soviet Union, along with a general decline in construction activity and in employment. Since the change to a market economy, the building industry has also been privatized and union membership is no longer compulsory, giving rise to changes in the gender division of work. The Czech Republic employers' federation (Svaz podnikateli ) reported that women were employed as construction workers, such as crane operators, during the communist period, but suggested that this has changed and that they are now working only in administrative and white-collar occupations.

\section{Obstacles to Women's Inclusion in Construction}

Both employer and employee organizations show a mixture of enlightenment and prejudice in their assessment of possible obstacles to women working and training in the construction industry. Some respondents saw no obstacles, including the Finnish Electrical Union (Sähköliitto), the Danish Painters' Union and the Bulgarian and Czech unions (although the latter conceded that the sector did not offer good working conditions). There were no marked differences between the responses of the trade unions and employers, apart from reference by two of the employers' federations to the selfexclusion of women and their lack of interest in working in the sector. Overall, the employers represented extremes, with at one end the German Zentralverband des deutschen Baugewerbes (ZDB), which was strongly negative, and at the other the French Fédération Française du Bâtiment (FFB), which was very positive that 'women in construction is possible'. Other respondents 
recognise barriers to the integration of women, highlighting the male domination of the industry in terms of its image, culture and practices and the slow pace of change.

Respondents identified a number of factors seen to constitute this 'male world' and possible obstacles to women's greater integration:

- $\quad$ About half mentioned the physical workload. The ZDB, representing craft employers, stated that although it supported women having the opportunity to work in manual occupations in construction, their scarcity suggested that they could not cope with the physical demands of the job. This essentially static view of the industry was countered by the Spanish union (ELA), which pointed out that although 'many people think the work is too heavy for women', the increasing use of machinery (and women taking up professional careers) should mean increasing numbers of women in the sector'. The Swedish employers' federation also acknowledged that 'we have to find new methods' to tackle the issue of 'heavy loads', whilst Dansk El-Forbund suggested that women's participation involved a division of tasks.

- Unfavourable working conditions such as the generally poor conditions on site, no washing and changing facilities for women, and the high level of accidents were mentioned as obstacles by a number of unions including FNV-Bouw and the British general union TGWU, and employers'organizations such as the Associaçao de Empresas de Construçao e Obras Publicas in Portugal, the Construction Confederation in the UK and FFB in France. Nearly all the respondents felt that the industry's working hours present a difficulty and are incompatible with childcare responsibilities.

- $\quad$ MCA-UGT, the Spanish union, suggested that employers' reluctance to hire women was at the root of their lack of participation. According to the German ZDB, employing women would require 'much stricter working and health regulations', thus imposing additional cost and organizational burdens on the employer.

- Organization of work: the Danish Forbundet Tra-Industri-Byg (TIB) suggested that the organization of work, mainly in 'close-knit gangs', acts as a barrier to the entry of any new person or atypical workers. This exclusive tendency of the gang system, closely linked to 
performance and wages, has been acknowledged by other research in the area as a barrier to the entry of women and ethnic minorities (Byrne et al., 2005). IG BAU also considered that subcontracting does not favour the integration of women in recruitment.

Recommendations for change by the social partners in our survey emphasised the need for women craftworkers to be more visible and for good practice to be disseminated. The FFB, for example, suggested that 'testimonies of female workers and the entrepreneurs hiring them seem like one of the best ways of communicating that women in construction is a possibility'. The Cypriot employers' federation, OSEOK, specifically mentioned promoting the opportunity for selfemployment to women. The need for government support in terms of public services and initiating equality measures was emphasized by the Czech, Spanish and Swiss unions. These reasons given by social partners echo those by firms in research on access to construction employment for women and ethnic minorities in Europe (EC Consortium, 2003).

\section{Women's Involvement in the Construction Unions}

One question posed in our survey was how far women participate in their union as delegates or representatives on health and safety, equal opportunity or women's committees (where these exist) and how far are they supported in this. Our survey shows that the level of women's involvement in the union generally reflects --- with some rare exceptions---their limited membership. Support measures, if available, are mostly related to the provision of training courses (Table 2). These are provided by several of the west European unions but none in the east, which with their already broad female participation do not see a necessity.

[Table 2 about here] 
The responses reflected the unions' approach and commitment to equal opportunities and the degree of women's activism, even if they are present only in small numbers. Differences in the approach to equal opportunities are highlighted by the examples of the Finnish and Swiss trade unions. The Swiss Gewerkschaft Bau und Industrie (GBI) has women's committees at national and regional levels and regulations concerning the proportional representation of women: all committees have to have at least two women and at least 30 percent of all trade union posts have to be filled by women. In contrast, The Finnish construction union (Rakennusliitto) claimed that 'women's involvement does not differ from men's. There are no special women's committees and gender issues are dealt with by the committee for cultural and gender issues.' In practice, Rakennusliitto is possibly the most active trade union of all those we surveyed in supporting women members and women in construction generally, providing women-only training courses, an annual women's conference and opportunities to network. The apparently understated Scandinavian position is perhaps attributable to the approach to equality measures and legislation in these countries, which falls within the socialdemocratic model whereby men and women engage as equal individuals in the labour market (Esping-Andersen, 1990). Whilst this is associated with a high level of female labour market participation, it also means that equality policies are firmly based on the principle of equal treatment and special measures for 'disadvantaged' groups have not been common (Michielsens et al., 2001; Peters, 1996).

In the Danish TIB, women's involvement exceeds their membership level: there are very few women (1 percent) but relatively high levels of union representation. One hundred women are shop stewards (7.5 percent of all shop stewards). Additionally this union has four female union officials and an official responsible for equality issues. The executive, youth, industrial, education and vocational training committees all have women representatives. One likely reason for this high representation is that shop stewards are mostly drawn from the more stable employment environment of the workshop, where tradeswomen are concentrated (as joiners and, to a lesser extent, upholsterers), rather than from construction sites with their less stable employment patterns (a difference also mentioned by the Italian FILCA-CISL). Another reason could lie in the history of the former Carpenters and Joiners' Union, which established an equal rights committee and a programme 
of meetings and activities for women in the 1980s (Fabricius, 1997). When this union amalgamated with TIB, the equal rights committee was merged into the general work of the union. The women's club situated in Copenhagen, however, continues to function on a voluntary basis.

Other unions reported that they are taking steps to increase women's involvement. The Swedish union Byggnads has run a two-week course on collective bargaining attended by 50 women, and has set up a women's network. The Swiss GBI aims to promote emancipation 'inside and outside' the union, including through courses for women members, regional women's committees, a national women's committee, a women's trade union representatives conference and a national women's conference held every two years. In Germany, a significant effort has been made to monitor the involvement of women in IG BAU. In general the higher up the hierarchy the fewer women to be found, though participation at local levels is mixed, with for instance a relatively high number of female delegates from areas such as Bonn whilst there are none from some other localities. There is a rather weak imposition of a quota whereby women are represented in the organization according to their level of membership (14.8 percent). Nevertheless two of the 56 district committees have female chairpersons and there are significant numbers of female works councillors, especially in cleaning (64 percent of the total) and painting (10 percent) and architectural and engineering offices (35 percent) (IG BAU, 2004). In general, therefore, female representation in the construction unions conforms with membership, with little attempt made to improve this, apart from in the Scandinavian countries.

\section{Support Measures to Promote Female Employment and Training}

A proactive approach to gender inclusion is indicated not only by female representation within the unions but also by specific measures taken to accommodate and encourage women. The social partners were therefore asked if support measures to promote the employment or training of women in construction were part of their agenda. These were specified as including clauses in collective 
agreements or participation in relevant networks or support programmes (concerning, for instance career guidance, training, recruitment, employment conditions, working time, childcare and other caring responsibilities, and health and safety).

In terms of collective agreements, clauses on maternity leave and maternity pay were most often mentioned and no specific clauses were identified relating to training or working time. The Danish Malerforbundet additionally has policies on working conditions during pregnancy, as does the Czech union. 'Positive action' was only mentioned by one respondent, the Italian FILCA-CISL, in relation to the wood industry, where 30 percent of employees are women. In Spain, MCA-UGT has measures to improve access and career progression for women and a policy of 'horizontal' agreements is being introduced whereby gains made by women in one sector are automatically applied across all sectors.

Overall, as apparent in Table 3, support is offered mostly in terms of participation in networks, though several unions also listed support programmes, for instance relating to childcare and health and safety or more general conditions of employment. Rakennusliitto in Finland is also involved in a special campaign in comprehensive schools to introduce construction occupations to girls, including visits to vocational schools. This was also the only union to refer to gender pay differentials as an important area of union concern. Women painters' pay is approximately 80 percent of men's, and such a gender pay differential applies to construction occupations generally in Finland and indeed throughout Western Europe.

[Table 3 about here]

Whilst union support policies and programmes are not common, participation in networks or conferences on women in construction or related subjects is rather more widespread, although specific women's networks are still scarce. In Britain, the TGWU has a link with the campaign group Women and Manual Trades. Rakennusliitto again provides a prime example of 'good practice' in its support for female painters through networks and conferences. It organizes an annual national women's conference, focusing on collective agreement policies (such as health and safety in 2002), 
social policies and broader societal questions. Involvement in the Femina Baltica network (a cooperation of Finnish Baltic women's organizations and the trade union movement in the Baltic countries) has led to participation in seminars in Lithuania, Latvia and Estonia on subjects such as violence towards women in their working life. The union acknowledges that such meetings have been very important for their women members as 'in the individual workplaces there are very few women employed'.

Almost no employer federation has staff members or units dealing with women's or equal opportunities issues or participates in women's networks or conferences. The Construction Confederation in the UK indicated activities relating to career guidance, training, recruitment, employment conditions, childcare arrangements and health and safety. The Norwegian Byggenceringens Landsforening also participates in the women's network of the peak confederation $\mathrm{NHO}$ and, though having no specific programmes to promote women, stated that: 'there is a general wish to have more women in the construction industry. Therefore the larger companies try to recruit women, also in high positions.' The Swedish Byggindustrier also reported that 'to meet the expected labour shortage our members have decided to widen the target group for recruitment to include both women and immigrants [and this is one of our] most important tasks'.

There are very few policies and programmes to support women's recruitment and retention in construction at the level of individual employers' federations or member firms. The French FFB reported policies specifically relating to women's recruitment and training, part of a nation-wide initiative, based on an agreement with six Ministries to promote the image of the sector and the training and employment of women. The FFB, uniquely, has also established a network of what are termed 'co-spouses' --- that is, women working with husbands and/or other family members in running a construction business. And some of the local FFB offices have set up projects with employment agencies and training centres for recruiting women.

Several projects concerned with training or encouraging women to work in the industry, and retaining those that succeed, have been launched under the EC EQUAL programme aimed at countering gender segregation (EQUAL, 2003). These have often involved collaboration with one or both of the social partners, though this was not in the main reported in the survey responses, possibly 
because it occurs at regional or local levels. Swedish union involvement in the EC Libra project (Byggnads) also aims to achieve a more even gender distribution in construction, partly by promoting courses in building techniques to girls at secondary school and university level. In Spain and Austria, projects involving social partners train women in a variety of construction skills. However, the transition from these schemes into the mainstream of the industry remains a formidable obstacle.

Overall, focused support measures related to the training, recruitment and retention of women in construction by either the unions or the employers' federations are not at all common, especially for skilled trades. There are some notable exceptions to the rule, such as the Finnish painters' union and the employers in France, Norway and Sweden. In the UK the employer-based Construction Industry Training Board (CITB) is also working with employers and other agencies in regionallybased 'collaborative partnerships' to increase female and ethnic minority representation in the industry.

\section{Conclusion}

The extent of male domination in skilled building work in Western Europe, little changed over the last twenty years, whilst not unexpected, is nonetheless still striking. The picture of uniformity is surprising in the context of the diversity of labour markets, welfare and industrial systems in Europe. The male domination of construction is one of the most extreme examples of labour market segregation. Eastern Europe, where there is significantly greater integration of women into the workforce, provides a contrast to the picture in the west. The survey data confirm the pattern of extreme segregation, extending to the social partner organizations themselves, with the notable exceptions of the Danish and Finnish female painters and the actions of the Finnish painters' union. Women's inclusion in the construction sector is not a priority issue (or even on the agenda) for the majority of the social partners. The responses reflect, on the one hand, the 'conservatism' of an industry where it still remains acceptable to suggest that women lack an increasingly less essential 
requirement to do the job, physical strength. On the other hand, the responses pander to a 'discourse' of gender equality, but one that does not automatically lead to equal opportunity policies or programmes. Indeed, the theoretical equality of women and men in the labour market was given several times as a reason for inaction.

In general, the social partners appear to have had little impact on the inclusion of women in the sector, showing more commitment in principle than in practice. The suggestions that only by changing production processes and by the increasing use of mechanization will women be allowed more access reflects the reluctance to address the often very different obstacles to inclusion from a variety of angles in a proactive way. Changing technology will not of itself bring about a change in the gender division of labour. And even with the removal of structural obstacles to integration, such as inappropriate and poor working and employment conditions and discriminatory recruitment practices, other more intangible obstacles will remain. The industry is still marked by a high level of health and safety risks in all countries, not improved by the persistence of a macho culture and the short-term concern with output at the cost of developing the potential of the workforce. This macho character, with its own language, jokes and working attitudes, continues to act as an important deterrent to entry by women. The social partners have the platform to start to make inroads and to change the industry from within, but still need to be encouraged to put women in construction on their agenda.

\section{REFERENCES}

\section{COPY-EDITOR: A LOT OF WORK NEEDED HERE I'M AFRAID!}

Bosch, G. and Philips, P. (2002) Building Chaos: regulation and deregulation in the construction industry, London: Routledge. 
Byrne, J., L. Clarke and M. van der Meer (2005) 'Gender and ethnic minority exclusion from European construction: an international comparison', paper submitted to Construction Management and Economics.

Byrne, J. and M. van der Meer (2002) 'Spain down the low track' in G. Bosch and P. Philips (eds), Building Chaos. Regulation and Deregulation in the Construction Industry, London: Routledge.

CITB (2002) Survey of Employment by Occupation in the Construction Industry 2001.

Clarke L., E. F. Pedersen, E. Michielsens, B. Susman and C. Wall (2004) Women in Construction, Reed International/CLR Studies 2.

Clarke L., E. F. Pedersen and C. Wall (1999) 'Balancing acts in construction: a study of two painters in Denmark and Britain', NORA - Nordic Journal of Women's Studies, 7 (2-3), 138-50.

Clarke, L., J. Cremers and J. Janssen (eds) (2003) EU Enlargement: construction labour relations as a pilot, CLR Studies 1, Reed International.

Clarke, L. and C. Wall (2000) 'Craft versus industry: the division of labour in European housing construction', Construction Management and Economics 18, 6, 689-98.

Clarke, L. and C. Wall (2004) 'Now you're in, now you're out: women's changing participation in the building trades in Britain' in L. Clarke et al. (eds) Women in Construction, CLR Studies 2, Reed International.

Cockburn, C. (1991) In the Way of Women: Men's Resistance to Sex Equality in Organizations, Basingstoke: Macmillan.

Colgan, F. and Ledwith, S. (eds) (2002) Gender, Diversity and Trade Unions: International Perspectives, London: Routledge.

Dickens, L. (2000) Collective bargaining and the promotion of gender equality at work: opportunities and challenges for trade unions in Transfer, 6, 2, 193-208.

EC Consortium (2003) Overcoming marginalization: structural obstacles and openings to integration in segregated sectors, Final Report, Report submitted to European Commission under TSER/RTD Framework 5 programme, University of Westminster. 
EIRO (2000) 'Equal opportunities, collective bargaining and the European employment strategy'. http://www.eiro.eurofound.ie/2000/05/study/tn0005402s.html

EIRO (2001) 'Construction workers' union to organise new groups of workers' http://www.eiro.eurofound.ie/2001/10/inbrief/de0110202n.html

EQUAL (2003) http://europa.eu.int/comm/employment_social/equal/index_en.html

Esping-Andersen, G. (1990) The three worlds of welfare capitalism, Cambridge: Polity Press.

EC (2001) Joint Employment Report, Luxembourg, Office for the Official Publications of the European Communities.

EC (2002a) European social statistics: Labour force survey results 2002, Luxembourg: Office for Official Publications of the European Communities

EC (2002b) Industrial Relations in Europe, DG Employment and Social Affairs, Luxembourg, Office for the Official Publications of the European Communities.

EC (2003) The sectoral social dialogue in Europe, DG Employment and Social Affairs, Luxembourg: Office for the Official Publications of the European Communities.

Fabricius, B. (1997) 'The Work for Equal Rights in the Carpenters and Joiners Union in

Copenhagen', CLR News 3, Brussels: European Institute for Construction Labour Research. FIEC (2002) FIEC Annual Report 2002, Brussels: FIEC .

Foley, J. R. (2003) 'Mobilization and change in a trade union setting: environment, structures and action', Work, Employment and Society, 17, 2, 247-68.

Gonäs, Lena (2004). Gender Segregation and the European Employment Strategy: Levels and Divisions, European Journal of Industrial Relations, 10, 2, p 139, 21p.

IFBWW (2003) Gender Equity http://www.ifbww.org/index.cfm?n=37\&l=2

IG BAU (2004) IG BAU:Typisch Frau, 6 Ordentliche Bundesfrauenkonforenz, Proceedings, Frankfurt.

Janssen J. (2004) 'Eine kulturschande': female labour in the German construction trades at the beginning of the cold war' in L. Clarke et al. (eds) Women in Construction, CLR Studies 2, Reed International. 
Kirton, G and A. Greene (2002) The dynamics of positive action in UK trade unions: the case of women and black members in Industrial Relations Journal, 33, 2, 157-72.

Léonard, E. (2001) 'Industrial Relations and the Regulation of Employment in Europe', European Journal of Industrial Relations, 7, 1, p 27, 21

McBride, A. (2001) Gender Democracy in Trade Unions, Aldershot: Ashgate.

Michielsens E., C. Wall and L. Clarke (1997) A Fair Day's Work---Women in the Direct Labour Organisations, London Women and Manual Trades (London) and Association of Direct Labour Organisations (Manchester).

Michielsens, E., L. Clarke and C. Wall (2000) 'Diverse Equality in Europe: The Construction Sector' in Mike Noon and Emmanuel Ogbonna (eds) Equality, Diversity and Disadvantage in Employment, Basingstoke: Palgrave.

Munro, A. (2001) 'A feminist trade union agenda? The continuing significance of class, gender and race', Gender, Work and Organisation, 8, 4, 454-71.

Parker, J. (2003) 'We're on a road to somewhere: women's groups in unions', Industrial Relations Journal, 34, 2, 164-84.

Pedersen, E. F. (2004) 'Painters in Denmark: a women's trade?' in L. Clarke et al., Women in Construction, CLR Studies 2, Reed International.

Peters, A. (1996) 'The Many Meanings of Equality and Positive Action in Favour of Women under European Community Law---Conceptual Analysis', European Law Journal, 2, 2, 177-96.

Pollert, A. (1999) 'Trade Unionism in Transition in Central and Eastern Europe', European Journal of Industrial Relations, 5 (July), 209-34.

Rubery, J., D. Grimshaw, C. Fagan, H. Figueiredo and M. Smith (2003). 'Gender equality still on the European agenda—but for how long?', Industrial Relations Journal, 34, 5, 477, 21p.

Schnepf, M., E. L. Laux and H. Baumann (1997) European collective bargaining in the building industry, Final Report, published by the Friedrich Ebert Foundation (FES) and European Federation of Building and Woodworkers.

UCL (2001) Report on the representativeness of European social partner organisations, part 2, Louvain- la-Neuve: IST 
Wajcman, J (2000) 'Feminism facing industrial relations in Britain', British journal of industrial relations, 38, 2, 183-202

Westerhuis, A. (2004) 'No women in construction; is education to blame?' in L. Clarke et al (eds) Women in Construction, CLR Studies 2, Reed International

LINDA CLARKE is Professor of European Industrial Relations at the University of Westminster. She is on the praesidium of the European Institute for Construction Labour Research.

ADDRESS: Westminster Business School, 35 Marylebone Road, London NW1 5LS, UK. [email: clarkel@westminster.ac.uk]

ELSEBET FRYDENDAL PEDERSEN is Associate Professor in the Department of Civil Engineering, Technical University of Denmark.

ADDRESS: BYG.DTU, 2800 Kongens Lyngby, Denmark. [e-mail: efp@byg.dtu.dk] ELISABETH MICHIELSENS is Senior Lecturer at the University of Westminster. [email: michiee@westminster.ac.uk]

BARBARA SUSMAN formerly Research Fellow at the University of Westminster. [e-mail: barbarasusman@yahoo.co.uk] 